\section{ACRL}

Official

\section{Statement}

\title{
ALA-SAA joint statement on access to original research materials: a draft
}

\section{Attend the bearings in Los Angeles on February 6, 1994}

\section{1}

A repository ${ }^{1}$ preserves collections $^{2}$ for

use by researchers. It is the responsibility of a repository to make available original research materials in its possession on equal terms of access. Access should be provided in accordance with statutory authority, institutional mandate, the Code of Ethics for Archivists, ${ }^{3}$ the "Standards for Ethical Conduct for Rare Book, Manuscript, and Special Collections Librarians," "4 and this joint statement. A repository should not deny access to materials to any researcher, nor grant privileged or exclusive use of materials to any researcher, nor conceal the existence of any body of material from any researcher, unless required to do so by statutory authority, institutional mandate, or donor or purchase stipulation.

\section{A repository is committed to preserv-} ing manuscript and archival materials and to making them available for research as soon as possible. At the same time, it is recognized that a repository may have legal and institutional obligations to protect confidentiality in its collections, and that private donors have the right to impose reasonable restrictions upon their papers to protect privacy or confidentiality for a reasonable period of time.

a. It is the responsibility of the repository to inform researchers of the restrictions which apply to collections.

b. The repository should discourage donors from imposing unreasonable restrictions and should encourage a specific time limitation on restrictions that are imposed.

c. The repository should periodically reevaluate restricted material and work toward the removal of restrictions when they are no longer required.

3. As the accessibility of material depends on knowing of its existence, it is the repository's responsibility to inform researchers of the collections in its custody. This may be accomplished through local, regional, or national catalogs; inventories and other internal finding aids; published guides; and the assistance of staff members.

4. To protect and insure the continued accessibility of the material in its custody, all materials must be used in accordance with the rules of the repository. Each repository should publish or otherwise make known to potential researchers its rules governing access and use. Such rules must be applied and enforced equally.

a. The repository may limit the use of fragile or unusually valuable materials, but should try to provide suitable reproductions to researchers in lieu of the originals.

b. The repository may limit access to unprocessed materials, so long as the limitations are applied and enforced equally.

c. The repository may, under special circumstances, loan or place on deposit with another repository part or all of a collection. ${ }^{5}$

d. The repository may refuse access to an individual researcher who has demonstrated such carelessness or deliberate destructiveness as to endanger the safety of the material, or to a researcher who has violated the policies and regulations of the repository.

e. To protect its collections, a repository may, in accordance with statutory authority and institutional mandate, require acceptable identification of any individual wishing to use its materials, as well as a signature verifying the individual has read a statement defining the policies and regulations of the repository. 


\section{A repository should not charge fees} for making available the materials in its holdings, except when required by statutory authority or institutional mandate. A repository should facilitate access to collections by providing reproduction services. These services can include electronic, paper, or photographic copies; microfilm; or other means of reproduction. All reproductions should be made in accordance with statutory authority, including copyright law, institutional mandate, and repository regulations. Reasonable fees may be charged for these copying or research services. A repository is not obligated to conduct copying or research services beyond those required by statutory authority or institutional mandate.

\section{Each repository should publish or} otherwise make available to researchers a suggested form of citation crediting the repository and identifying items within its holdings for later reference. Citations to copies of materials in other repositories should include the location of the originals, if known

\section{It is the researcher's} obligation to satisfy copyright regulations when copying or using materials found in collec tions. ${ }^{6}$ Whenever possible a repository should inform a researcher about known copyrighted material, the owner or owners of the copyrights, and the re-searcher's obligations with regard to such material.

\section{Notes}

${ }^{1}$ A repository is defined as an archives, manuscripts library, research center, or any other in stitution responsible for keeping primary research materials.

${ }^{2}$ Collections are defined as individual manuscripts, archival or manuscript collections, fonds, or record groups found in repositories in any format.

${ }^{3}$ Code of Ethics for Arcbivists and Commentary (Chicago: Society of American Archivists, 1992)

4"Standards for Ethical Conduct for Rare Book, Manuscript, and Special Collections
Librarians, with Guidelines for Institutional Practice in Support of the Standards," CERL News 54 (April 1993): 207-15.

${ }^{5}$ Repositories wishing to participate in the interlibrary loan of materials may consult as a model the "Additional Guidelines for Access to Archives, Manuscripts, and Special Collections," Chapter 8 of the RLG Shared Resources Manual, 3rd ed. (Stanford, Calif.: Research Libraries Groups, 1987). The chapter is reprinted in Rare Books \& Manuscripts Librarianship 3 (Fall 1988): 126-30. Repositories wishing to loan original materials for research or exhibition may consult the RBMS "Guidelines for the Loan of Rare and Unique Materials," CERL News 54 (May 1993): 267-69, or the "Guidelines for Borrowing Special Collections Materials for Exhibition," CERL News 51 (May 1990): 430-34

${ }^{6}$ Repositories may wish to provide researchers with the American Library Association's publication, Locating Copyright Holders (Chicago: ALA, 1991).

\section{Development of this statement}

This proposed revision of the ALA-SAA Joint Statement on Access to Original Research Materials has been submitted by the ALA/SAA Joint Commiltee on Library-Archives Relationships and is published here to insure broad professional review. It is a revised version of the ALA-SAA Joint Statement on Access to Original Research Materials in Libraries, Archives, and Manuscript Repositories developed jointly in 1978 by the Rare Books and Manuscripts Section (RBMS) of ACRL and the Society of American Archivists (SAA) Committee on Reference and Access Policies (C\&RL News 40, April 1979, pp. 111-12).

In response to a request for periodic review by ACRL, RBMS established a Committee on Access Guidelines, chaired by Robert Blesse. This committee prepared the initial revision and then referred the document to the ALA/SAA Joint Committee. This final compilation was prepared by a working group appointed by the Joint Committee. Members of the working group were Mork Vargas (chair), Cathy Henderson, Timothy Murray, and Elena Danielson.

This proposal updates the existing statement and further defines the responsibilities of repositories in providing effective and equitable access to original research materials, but it does not depart substantially from the previous policy. It was approved for publication and review by the RBMS Executive Committee in June 1993, and a hearing is scheduled for the ALA Midwinter Meeting in Los Angeles from 9:30-11:00 a.m. on Sunday, February 6, 1994. Written comments should be addressed to: Thomas Hickerson, Cornell University, 2B Carl A. Kroch Library, thaca, NY 14853; or e-mail: hth2@cornell. edu. 